\title{
Improvement of CBERS-3 satellite imaging camera components by plasma immersion ion implantation on SS304
}

\author{
melhoria de componentes da câmera do satélite CBERS-3 por \\ implantação iônica por imersão em plasma em aço inoxidável 304
}

Bruno Bacci Fernandes ${ }^{1,2}$, Mario Ueda ${ }^{1}$, Carina Barros Mello ${ }^{1}$, Carlos Mauricio Lepienski ${ }^{3}$, Helfried Reuther ${ }^{4}$,

Sérgio Henrique Evangelista ${ }^{5}$

\begin{abstract}
Camera components made of stainless steel (SS304) and Ti-6Al-4V alloy are used as anti-vibrator stoppers (pin-pull) for the focusing imaging system embedded in satellites that are remotely operated. Vibration tests for the certification China-Brazil Earth Resources Satellite 3 (CBERS-3) generated galling problems in some parts of these components. Nitrogen plasma immersion ion implantation (N-PIII) was an useful technique to enhance the surface properties of these components and consequently to overcome such problems. This work shows the characterization of implanted SS304 samples to explain the surface modifications that allow the improving of the mentioned components. X-ray diffraction (XRD) analysis of the samples indicated that N-PIII at $12 \mathrm{kV}$ form expanded austenite phase with 0.7 micrometers of thickness and atomic force microscopy (AFM) showed a typical nodular morphology at the surface. Hardness measurements revealed a significant increase in the surface hardness after N-PIII treatment. Wear tests using a pin-on-disc device showed an increase in wear resistance and a reduction in the friction coefficient. Such observed surface modifications successfully prevented galling in the pin-pull camera parts through the reduction of the adhesive mechanisms.
\end{abstract}

Keywords: Plasma immersion ion implantation; Stainless steel; Satellite components; Galling

\section{RESUMO}

Componentes de câmeras, feitos de aço inoxidável 304 e da liga Ti$6 \mathrm{Al}-4 \mathrm{~V}$, são utilizados como travas anti-vibração para o sistema de foco de imagem de satélites que são remotamente operados. Testes de vibração para a certificação do CBERS-3 geraram problemas de emplastamento em algumas partes dos componentes mencionados. A implantação iônica de nitrogênio foi uma técnica que possibilitou a melhoria das propriedades superficiais destes componentes e consequentemente a superação dos problemas encontrados. Este trabalho mostra a caracterização das amostras de aço inoxidável 304 para explicar as modificações superficiais que permitiram a melhoria nos componentes da câmera. A análise de difração de raios $\mathrm{X}$ das amostras indicou que a implantação a $12 \mathrm{kV}$ forma a fase austenita expandida com 0,7 micrometros de espessura, e a microscopia de força atômica mostrou que a morfologia superficial é nodular. Medições de dureza revelaram um aumento siginificativo dessa propriedade após a implantação. Os testes de desgaste do tipo pin-on-disc mostraram um aumento na resistência ao desgaste e uma redução no coeficiente de atrito. Tais modificações superficiais evitaram o esfolamento nas peças da câmera através da redução do desgaste adesivo

Palavras-chave: Implantação iônica por imersão em plasma, Aço inoxidável, Componentes de satélite, Esfolamento.

\footnotetext{
IInstituto Nacional de Pesquisas Espaciais - Laboratório Associado de Plasma - São José dos Campos, SP - Brazil ZUniversidade Braz Cubas - Mogi das Cruzes /SP-Brazil

${ }^{3}$ Universidade Federal do Paraná - Departamento de Física - Curitiba/PR - Brazil

${ }^{4}$ Institute of Ion Beam Physics and Materials Research -Dresden, Germany

${ }^{5}$ Opto Pesquisa e Desenvolvimento S. A. - São Carlos, SP- Brazil

Correspondence author: Bruno Bacci - Fernandes Instituto Nacional de Pesquisas Espaciais - Laboratório Associado de Plasma - Av. dos Astronautas, 1758- Jardim da Granja - CEP: 12227-010 São José dos Campos, SP - Brazil

Email: baccicss@gmail.com

Received: 13/06/2017 Approved: 23/06/2017
} 


\section{INTRODUCTION}

In practical engineering applications, many failures of parts begin frequently from their surface through wear, fatigue, corrosion, and so on. Therefore, durability against damages of components can be improved by strengthening their surface region $^{(1)}$. Failure as thread galling commonly happens in oil country tubular goods (OCTG) connections. Galling has also been observed in products and tools of sheet metal forming processes, as well as in some medical, aerospace and aeronautical parts ${ }^{(2-4)}$. Friction between local contact points produces cold welding because of the severe plastic deformation as well as the local high temperature ${ }^{(2)}$. Galling is a severe adhesive wear that occurs under conditions of non- or poor lubrication and high contact pressure when relative motion exists between the contacting surfaces ${ }^{(5,6)}$. In extreme cases, galling can be accompanied by cold welding of the mated parts ${ }^{(3)}$. Materials that are susceptible to galling generally form a passive film on the surface, such as aluminum, titanium and stainless steel $(\mathrm{SS})^{(7)}$. Austenitic SS is a very sticky material in sliding contact at room temperature ${ }^{(8)}$ and conventional titanium alloys are chemically active and exhibit strong adhesion when in contact with themselves or other materials ${ }^{(4)}$.

Several solutions were proposed to reduce galling, which will be summarized in the next phrases. Friction tests of Ti-6Al-4V alloy with nickel coatings against this same alloy with $\mathrm{CrCN}$ coating show a reduction in wear of $13.5 \%$ as compared to the CuNiIn coatings $^{(9)}$. When TiC/Ti-6Al-4V alloy is brought into contact with multiwalled carbon nanotubes (MWNT), diamond-like carbon/chromium (DLC/Cr), graphite-like carbon/chromium (GLC/Cr) and $\mathrm{MoS}_{2} / \mathrm{Ti}$ coatings, galling does not occur in the conditions adopted ${ }^{(4)}$. Carbon-based coatings or nitrogen alloying of powder metallurgy tool steels have shown promising results to solve such trouble. Adhesion wear was reduced in these studies when such materials slid against different carbon steels ${ }^{(10,11)}$.

Oxidation, corrosion and wear of SS components used in the satellites are actual problems, in particular for the pin-pull components of CBERS-3. All satellite components are subjected to severe vibration during their launching by rockets. Afterwards, many of these components must operate remotely, and if they are affected by severe galling, malfunctions can be occur at space compromising the whole project.

Besides the several advantages of the PIII method ${ }^{(12,13)}$, the possibility of suppression of $\mathrm{CrO}_{3}$ feedstock in surface treatment of SS must be emphasized ${ }^{(14)}$. Homogeneous chromium-rich oxide films can improve corrosion properties of SS as mentioned in researches involving selective oxidation of chromium at low oxygen partial pressure(15). For SS304, an oxide layer is naturally formed at the surface after PIII, however the treatment temperatures must be limited to $450^{\circ} \mathrm{C}$ in order to avoid the formation of $\mathrm{CrN}$, which reduces its corrosion resistance ${ }^{(16-18)}$. Lower temperature limit is mentioned in other research for such successful nitrogen implantation, however the treated material and the PIII method are different ${ }^{(19)}$. Otherwise, recent researches have shown that PIII improves wear resistance and hardness of SS304 through formation of expanded austenite, i.e. a nitrogenrich phase obtained at temperatures below $500^{\circ} \mathrm{C}^{(20)}$. PIII combine several abilities such as the non-line-of-sight advantage for treatment of large components with complex geometries ${ }^{(21)}$. Surface of SS304 was also modified by PIII with auxiliary heating presenting a maximum implanted depth of $5 \mu \mathrm{m}$. PIII without auxiliary heating introduces a lower nitrogen peak concentration and a maximum depth of $810 \mathrm{~nm}^{(16)}$.

Galling occurred on Ti-6Al-4V/ SS304 and SS304/SS304 couples contacts after vibration tests of the CBERS-3, when no additional surface treatment was applied to such contacts. For this reason, an N-PIII was carried out and this problem was successfully solved. Other methods were previously employed - e.g. heat treatments and plasma nitriding - without success to solve the galling problem. The present study aims to describe how PIII affects the wear behavior of SS304, but also presents a detailed study on the formed phases produced by this technique.

\section{EXPERIMENTAL PROCEDURE}

The SS304 samples used in this work has the following composition: $19.00 \mathrm{Cr}, 11.00 \mathrm{Ni}, 0.03 \mathrm{C}, 1.50 \mathrm{Mn}, 2.00 \mathrm{Si}$ and $66.47 \mathrm{Fe}$ (wt.\%). For PIII treatment, the samples were polished using silicon carbide emery papers starting from 300 to 1200 grade and finished up using alumina powder of $0.25 \mu \mathrm{m}$. The samples were ultrasonically cleaned before loading into the PIII apparatus. The experimental set-up for the present N-PIII processing of SS304 is shown in Fig.1, and discussed in more detail elsewhere ${ }^{(22)}$.

The system was pumped down to a base pressure of $4.5 \times 10^{-5}$ mbar. From this condition, the operating pressure of $6.5 \times 10^{-3}$ mbar was achieved by introducing nitrogen $\left(\mathrm{N}_{2}\right)$ into the chamber. The substrate was negatively biased to a voltage of $12 \mathrm{kV}$, and the implantation was carried out with pulses of $50 \mu$ s at a frequency of $300 \mathrm{~Hz}$, for 180 and 270 minutes. The

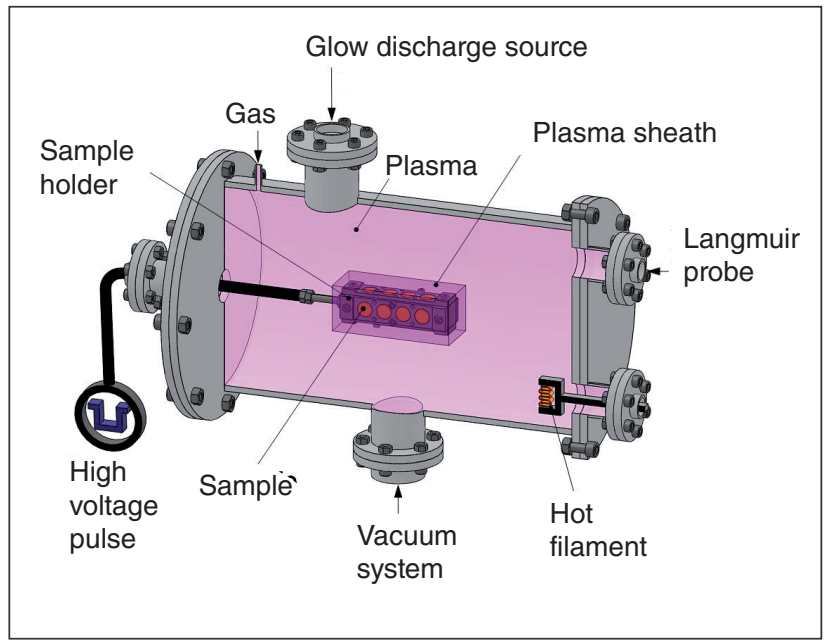

Figure 1: PIII device. 
sample temperatures were kept around $350^{\circ} \mathrm{C}$ according a Raytec infrared pyrometer. The current density presented values around $7 \mathrm{~mA} / \mathrm{cm}^{2}$ during the high voltage pulses.

Samples were characterized by X-ray diffraction (XRD) using a Philips PW1830 diffractometer with CuKa radiation and a high-resolution Philips X'Pert MRD X-ray diffractometer in the Bragg-Brentano Grazing Incidence (GIXRD) mode. The pristine samples were etched with acqua regia reagent and analyzed by scanning electron microscope for grain size measurement. Surface morphology was verified by atomic force microscopy (AFM) operating a Shimadzu SPM-9500J3 in the dynamic mode. Auger electron spectroscopy (AES) depth profiling was used in order to obtain the depth dependence of the chemical composition from the surface region. AES profiles were obtained by using argon ions for sputter etching in a Microlab 310-F spectrometer.

The dry wear behavior of the SS304 was studied by means of a CMS Tribometer in ball-on-disk mode, where a tungsten carbide (WC) ball of 3-mm diameter was scratched against the SS304 samples surface with velocity of approximately $10 \mathrm{~m} / \mathrm{s}$ at a constant load of $2 \mathrm{~N}$. Surface hardness and modulus were measured using a MTS nanoindenter. The SS samples used in these analyses have 15-mm diameter per 2-mm thickness.

Pin-pull components of the camera were treated together with the mentioned samples. They were also submitted to qualification procedures, which include vibration tests using frequencies from 20 to $2000 \mathrm{~Hz}$ and functional tests. These tests were performed according to TX/SATEC Vibration Test Specification with sine and random modes.

\section{RESULTS AND DISCUSSION}

SS304 samples have the average grain size of ASTM 4.5 and after PIII treatments they exhibited a slight changing in their apparent color. Figure 2 shows the X-ray diffractogram of SS304 subjected to N-PIII for 3 hours together with an untreated one. The untreated alloy exhibits the fcc $\gamma$-austenite phase and the bcc

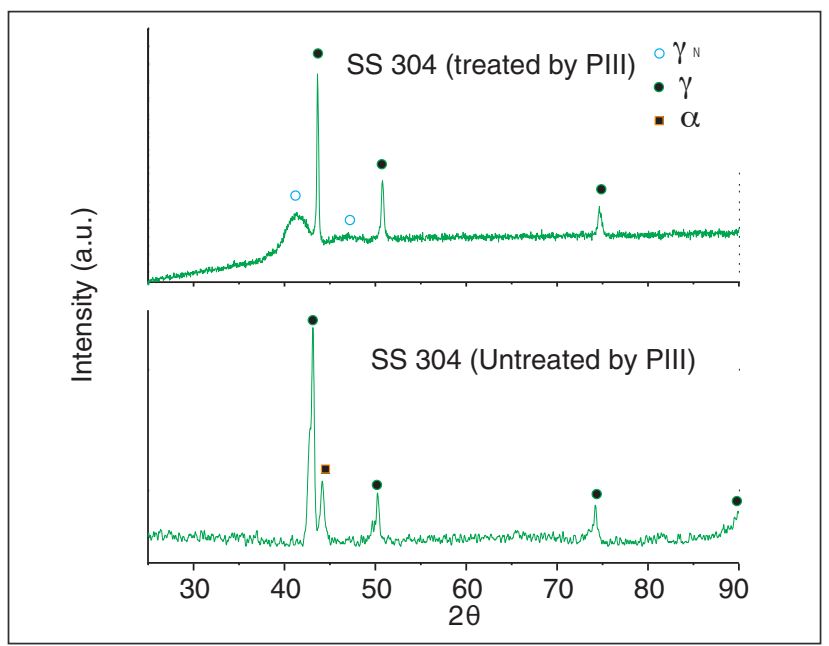

Figure 2: X-ray diffractograms of treated and untreated SS304. $\alpha$-martensite phase (only at surface areas). On the other hand, PIII treatment yielded a nitrogen-rich expanded austenite $\left(\gamma_{\mathrm{N}}\right)$ phase at surface, which is very similar with N-PIII for 4.5 hours at different conditions ${ }^{(16)}$.

The expanded austenite appears in greater quantity at few nanometers from the surface, and the original austenite phase gradually becomes dominant until approximately $1 \mu \mathrm{m}$ that it is unique, as verified by GIXRD spectra (Fig. 3). It is noteworthy that such analysis must be done only with additional characterization data, because there are inherent restrictions for a direct attribution of XRD data to nitrogen depths ${ }^{(23)}$. As noticed by Czerwiec and co-workers ${ }^{(24,25)}$, a small content of the other expanded austenite is also detected but only at surface layers in the present work. The $\mathrm{CrN}$ phase was not identified even in a low omega angle of $1^{\circ}$.

Through AFM technique, the surface topographies of untreated and PIII treated samples could be observed (Fig. 4). Such images show that the treated surface is covered by nodular morphology

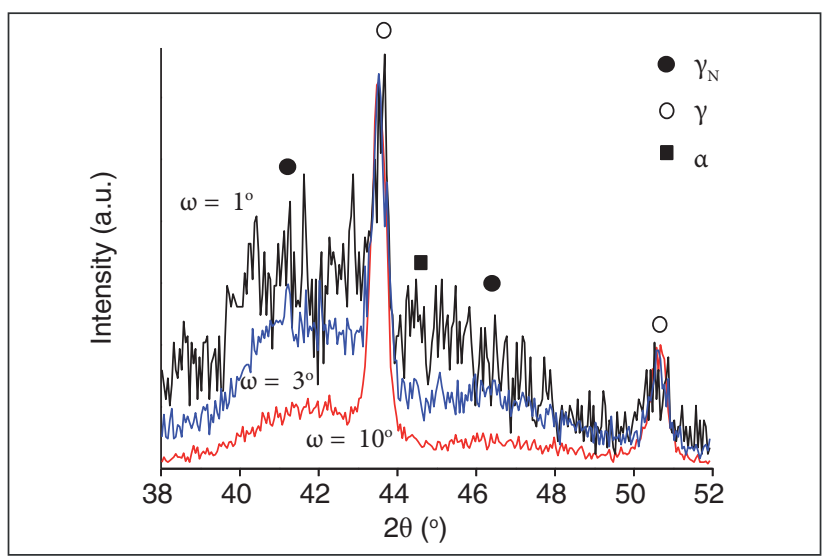

Figure 3: Glancing incidence X-ray diffractograms of treated SS304.

A

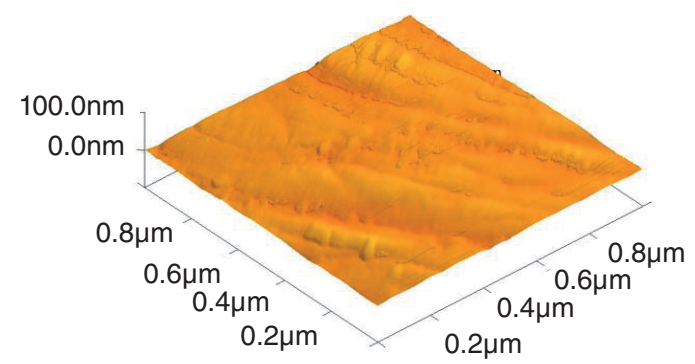

B

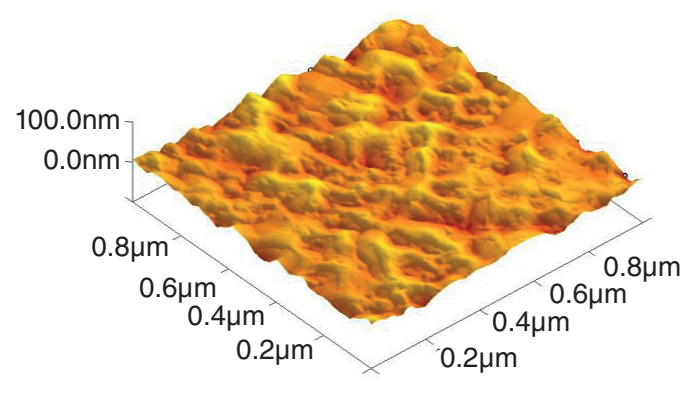

Figure 4: (A) AFM - untreated sample; (B) AFM - sample treated by PIII. 
with homogeneous grain distribution, what is different from the pristine sample (Fig. 4a) that has a flattened structure. After the plasma treatment, roughness increased from $1.8 \mathrm{~nm}$ to $5.5 \mathrm{~nm}$ (measured area of $1 \mu \mathrm{m}^{2}$ ) and from $3.2 \mathrm{~nm}$ to $8.1 \mathrm{~nm}$ (measured area of $25 \mu^{2}$ ). Such new morphology can be related to grain-tograin swelling observed in recent studies ${ }^{(26)}$.

Figure 5 displays the AES depth profiles of the pristine SS304 together with the nitrogen and the other impurities acquired from the N-PIII. The first atomic layers from the surface were slightly contaminated by species such as oxygen and carbon. These elements were confined to less than $25 \mathrm{~nm}$ while the most important element present in the subsurface of treated layer is nitrogen. The maximum nitrogen depth was about $700 \mathrm{~nm}$, and a maximum concentration of 30 at.\% could be achieved at a depth of about $20 \mathrm{~nm}$. The level of nickel does not changed significantly while iron and chromium had a reduction because the nitrogen implantation, which can be explained by a preferentially $\mathrm{N}$ bonding with $\mathrm{Fe}$ and $\mathrm{Cr}^{(27)}$.

Despite the relatively high content of nitrogen, as mentioned earlier, the $\mathrm{CrN}$ phase was not detected by XRD analysis, which is essential to avoid the deterioration of SS304's corrosion properties $^{(16,19)}$. The reliability of the PIII method must be highlighted regarding the repeatability of the treated layer.

Figure 6 shows the experimental results of surface hardness obtained from nanoindentation tests. The implanted samples

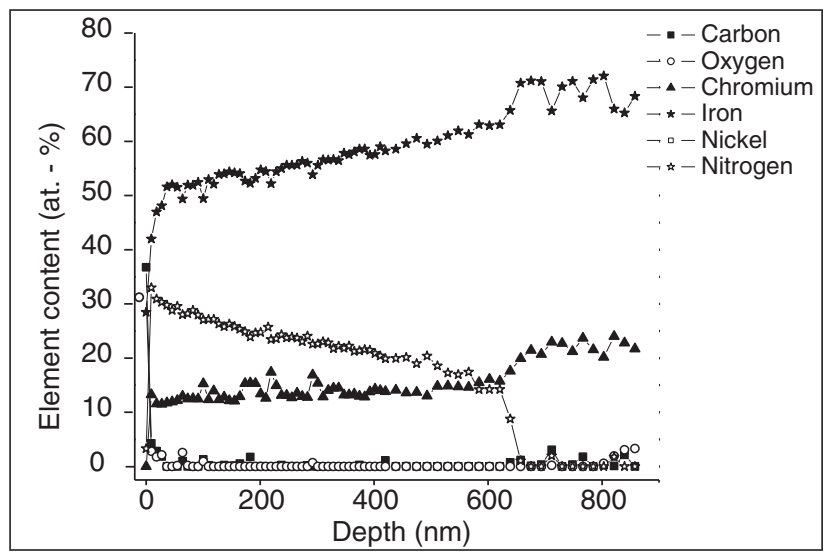

Figure 5: AES results of elemental concentration at SS304 surface.

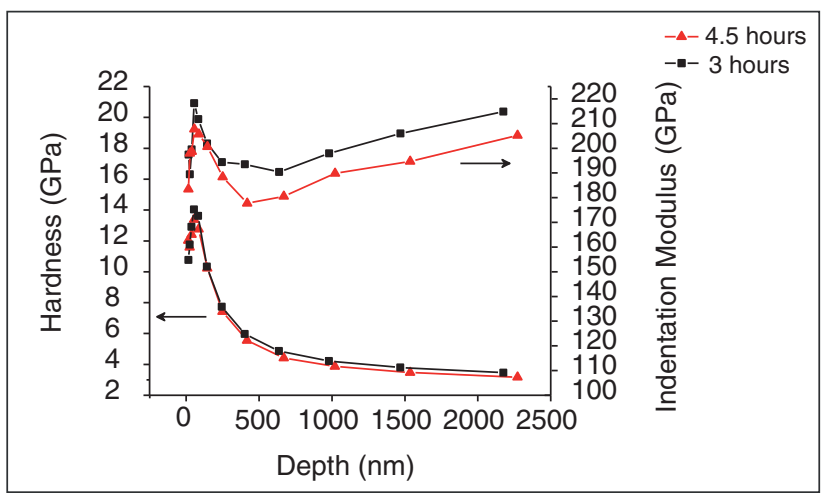

Figure 6: Hardness and indentation modulus profiles of PIII treated SS304. exhibit maximum hardness of about two times the values of the untreated alloy, which is around 7-8 GPa at the first atomic layers $^{(16,28)}$. As found in another study, indentation modulus is almost independent of the nitrogen concentration distribution and the penetration depth ${ }^{(29)}$.

Figure 7 shows the variation on friction coefficient of the untreated and PIII treated SS304 samples. PIII treatment has considerably improved the wear resistance of SS304, especially because the volume loss after the wear tests. The samples treated for $3 \mathrm{~h}$ showed better resistance (volume loss of $144 \mathrm{~mm}^{3}$ ) than the sample treated for $4.5 \mathrm{~h}\left(176 \mathrm{~mm}^{3}\right)$ and the untreated one $\left(231 \mathrm{~mm}^{3}\right)$. The values of volume wear were obtained by measuring the scar marks left by the pin scratches after 10,000 revolutions.

The initial rapid increase (less than 100 revolutions) in the friction coefficient indicates the removal of the adsorbed layer (with $\mathrm{C}$ and $\mathrm{O}$ ). This increase is slower in the treated samples because of another differentiated layer, i.e. expanded austenite. The running-in period of the wear tests is more pronounced in the untreated sample, although the coefficient in the steady state stage of the treated ones is slightly superior. Such latter feature was not enough to increase the wear rate of the treated samples. The high hardness of the modified layer provides superior tribological performance by an improved abrasive wear resistance $e^{(30,31)}$.

The scar images (Fig. 8) show that the PIII decreases the adhesion mechanisms such relatively long tests, which explain the suppression of galling in vibration tests of the satellite components.

Assembled CBERS-3 imaging camera was submitted to extensive testing in a simulated space environment performing the qualification tests similar to that described by Tosetto et al. ${ }^{(32)}$. The vibration test was carried out with a random frequency $(20-2000 \mathrm{~Hz})$ for 2 minutes per axis (xyz), where the rigid fixation components without the layer produced by PIII suffered galling. After the PIII treatment with nitrogen, these parts surpassed the aforementioned tests, because a perfect functioning of the remotely controlled camera focusing mechanism could occur afterwards. The crucial reason for this success is the suppressing of galling in such components. These components compose a part of an anti-vibration stopper that avoids any damage on the focusing

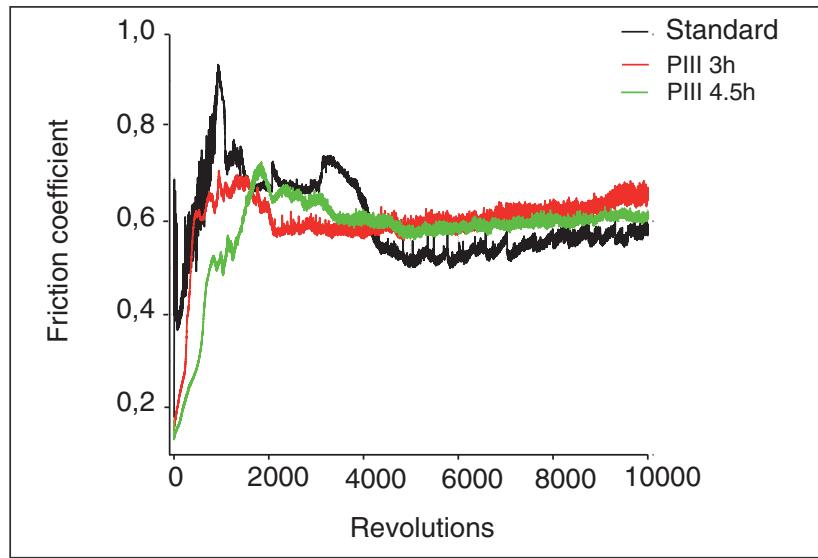

Figure 7: Friction coefficient curves of the SS304 alloys. 
system of the camera during the severe stage of launching. Such components are depicted in Fig. 9, where a pen is also shown for size comparison. It must be pointed out that even such shallow nitrided layer can be adopted to improve dramatically the metallic surfaces on some applications with successful results.

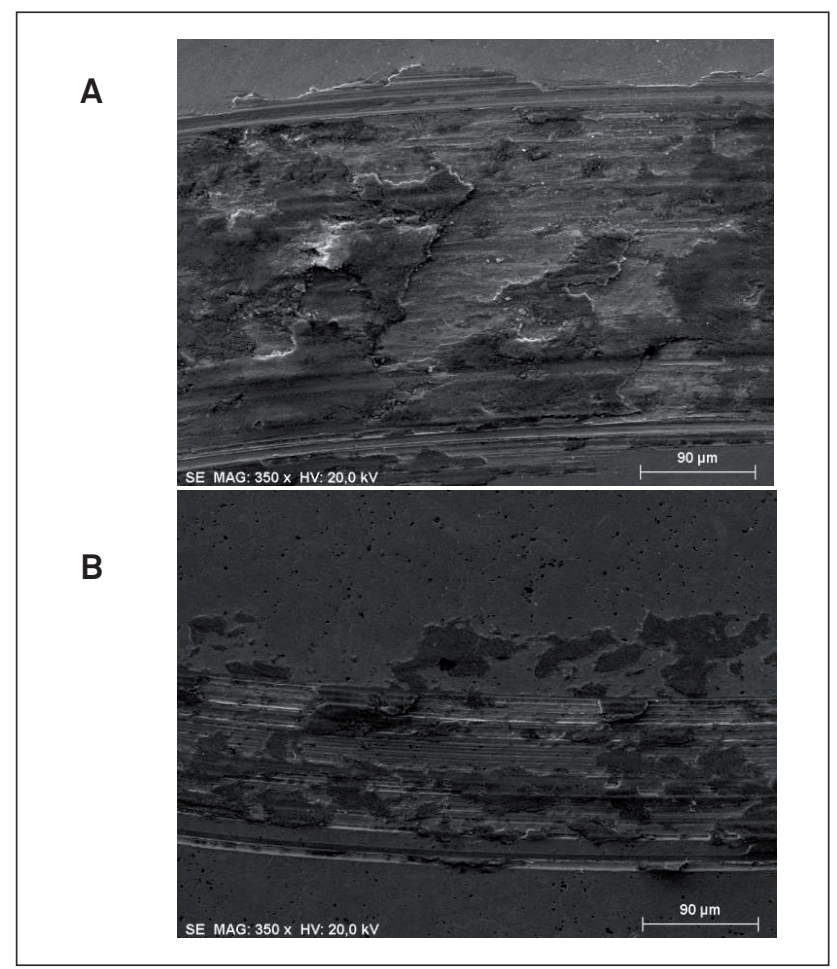

Figure 8: Scar images obtained from SEM of: (A) untreated sample; (B) sample treated by PIII.

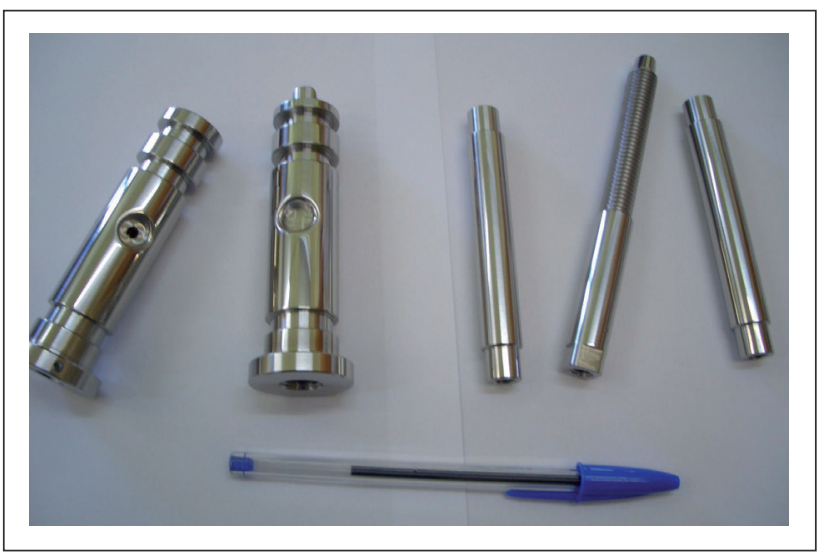

Figure 9: Camera components treated by PIII.

\section{CONCLUSIONS}

N-PIII treatment on SS304 using 12-keV energy was successfully used to implant nitrogen to a depth of approximately $700 \mathrm{~nm}$. XRD results revealed the existence of expanded austenite in the SS304 surface subjected to such treatment. Hardness and wear resistance of the treated SS304 has been found to increase significantly after such implantation. Corrosion resistance was maintained (not shown in this work but seen elsewhere ${ }^{(33)}$ ), which can be corroborated by the very low content of $\mathrm{CrN}$.

Even this relatively shallow layer avoided galling on components of CBERS-3 camera during simulation tests of pin-pull elements, which are actuated remotely (as in the real time satellite operation in space). It is noteworthy that a relative simple configuration was used to produce such protective layer, where only nitrogen gas was implanted rather than using gas mixtures or deposition schemes. Advantages as lower costs and favorable sheath geometries must be highlighted ${ }^{(34)}$. This is a new option to solve the galling problem in extremely sensitive components as the ones used in space or in medical grounds, besides other solutions described in the previous work, such as wet lubrication, $\mathrm{Zn}-\mathrm{Ni}$ coatings or the changing of materials ${ }^{(7)}$. The little modification of the dimensions of the parts is another important advantage of the PIII method used here, specially for applications in space components.

\section{ACKNOWLEDGEMENTS}

The authors acknowledge Maria Lúcia Brison for SEM analysis, Filipe Estevão de Freitas for help with the AFM and several other co-workers at INPE. This work was partially supported by the FAPESP (Grant Nos. 2011/00872-2 and 2012/21009-3, Sao Paulo Research Foundation) and CNPq (National Council of Research and Development) funding agencies.

\section{REFERENCES}

1. S. K. GHOSH, P. K. LIMAYE, B. P. SWAIN, N. L. SONI, R. G. AGRAWAL, R. O. DUSANE, A. K. GROVER, Surf. Coat. Techn. 201 (2007) 4609-4618.

2. Y. GUANGJIE, Y. ZHENQIANG, W. QINGHUA, T. ZHENTONG, Eng. Failure Analysis, 13 (2006) 1275-1284. https://doi.org/10.1016/j. engfailanal.2005.11.006

3. S. R. HUMMEL, Tribology Int., 41 (2008) 175-180. https://doi. org/10.1016/j.triboint.2007.07.009

4. K. MIYOSHI, J. H. SANDERS, C. H. HAGER JR., J. S., ZABINSKI, R. L. V. WAL, R. ANDREWS, K. W. STREET JR., B. A. LERCH, P. B. ABEL, Tribology Int., 41 (2008) 24-33. https://doi.org/10.1016/j. triboint.2007.04.006

5. K. GURUMOORTHY, M. KAMARAJ, K. P. RAO, S. VENUGOPAL, Mater. Design, 28 (2007) 987-992. https://doi.org/10.1016/j. matdes.2005.11.018

6. M. P. PEREIRA, W. YAN, B. F. ROLFE, Wear 268 (2010) 1275-1284. https://doi.org/10.1016/j.wear.2010.01.020

7. S. S. M. TAVARES, J. M. PARDAL, J. S. CORTE, C. SCANDIAN, L. F. G. HERCULANO, Eng. Failure Analysis, 16 (2009) 1765-1769.

8. M. HANSON, N. STAVLID, E. CORONEL, S. HOGMARK, Wear 264 (2008) 781-787. https://doi.org/10.1016/j.wear.2006.11.056

9. C. H. HAGER JR., J. SANDERS, S. SHARMA, A. VOEVODIN, Wear, 263 (2007) 430-443. https://doi.org/10.1016/j.wear.2006.12.085

10. A. GÅÅRD, P. KRAKHMALEV, J. BERGSTRÖM, Tribol. Lett., 33 (2009) 45-53. https://doi.org/10.1007/s11249-008-9390-6 
11. A. GÅÅRD, P. KRAKHMALEV, J. BERGSTRÖM, Wear 267 (2009) 387-393.https://doi.org/10.1016/j.wear.2008.11.013

12. A. ANDERS (Ed.), Handbook of Plasma Immersion Ion Implantation and Deposition, 1st edition, J. Wiley and Sons Inc., Toronto, 2000.

13. M. UEDA, L. A. BERNI, R. M. CASTRO. Surf. Coat. Technol. 200 (2005) 517-520.

14. N. SERRES, F. HLAWKA, S. COSTIL, C. LANGLADE, F. MACHI, A. CORNET, Surf. Coat. Technol. 204 (2009) 197-204.

15. B. CHO, S. CHUNG, K. KIM, T. KANG, C. PARK, B. KIM, Applied Surf. Sci. 173 (2001) 22-29. https://doi.org/10.1016/S01694332(00)00898-9

16. C. B. MELLO, M. UEDA, C. M. LePIENSKI, H. REUTHER, Appl. Surf. Sci., 256 (2009) 1461-1465. https://doi.org/10.1016/j. apsusc.2009.09.001

17. D. MANOVA, F. SCHOLZE, S. MÄNDL, H. NEUMANN, Surf. Coat. Technol. 205 (2011) S286-S289

18. G. THORWARTH, S. MÄNDL, B. RAUSCHENBACH, Surf. Coat. Technol. 125 (2000) 94-99. https://doi.org/10.1016/S02578972(99)00605-2

19. C. ANADAN, V. K. W. GRIPS, V. E. SELVI, K. S. RAJAM, Surf. Coat. Technol. 201 (2007) 7873-7879. https://doi.org/10.1016/j. surfcoat.2007.03.034

20. I. E. SAKLAKOGLU, N. SAKLAKOGLU, K. T. SHORT, G. A. COLLINS, Mater. Design 28 (2007) 1657-1663. https://doi. org/10.1016/j.matdes.2006.02.008

21. X. TIAN, R. K. Y. FU, L. WANG, P. K. CHU, Mater. Sci Eng. A 316 (2001) 200-204. https://doi.org/10.1016/S0921-5093(01)01245-X

22. M. UEDA, L. A. BERNI, J. O. ROSSI, J. J. BARROSO, G. F. GOMES, A. F. BELOTO, E. ABRAMOF, Surf. Coat. Technol. 136 (2001) 2831.
23. J. LUTZ, D. MANOVA, J. W. GERLACH, M. STÖRMER, S. MÄNDL IEEE Trans. Plasma Sci. 39 (11) (2011) 3056-3060. https://doi org/10.1109/TPS.2011.2160292

24. T. CZERWIEC, N. RENEVIER, H. MICHEL, Surf. Coat. Technol. 131 (2000) 267-277. https://doi.org/10.1016/S0257-8972(00)00792-1

25. T. CZERWIEC, H. HE, S. WEBER, C. DONG, H. MICHEL, Surf Coat. Technol. 200 (2006) 5289-5295. https://doi.org/10.1016/j. surfcoat.2005.06.014

26. J. C. STINVILLE, C. TEMPLIER, P. VILLECHAISE, L. PICHON, J. Mater. Sci. 46 (2011) 5503-5511. https://doi.org/10.1007/s10853011-5494-8

27. M. K. LEI, X. M. ZHU, J. Vac. Sci. Technol. A 22 (5) (2004) $2067-$ 2070. https://doi.org/10.1116/1.1786305

28. M. UEDA, G. F. GOMES, E. ABRAMOF, H. REUTHER, Surf. Coat. Technol. 186 (2004) 291-294.

29. J. F. LIN, K. W. CHEN, C. C. WEI, C. F. Al, Surf. Coat. Technol. 197 (2005) 28-38. https://doi.org/10.1016/j.surfcoat.2004.07.105

30. J. YANG, Y. LIU, Z. YE, D. YANG, S. HE, Tribol. Lett. 40 (2010) 285294.

31. M. V. LeITE, C. A. FIGUeROA, S. C. GALLO, A. C. ROVANI, R. L. O. BASSO, P. R. MEI, I. J. R. BAUMVOL, A. Sinatora, Wear 269 (2010) 466-472. https://doi.org/10.1016/j.wear.2010.04.037

32. I. TOSETtO, R. ARAUJO, C. GONÇALVES, J. A. RODRIGUES, Microwave and Optoelectronics Conference, 1 (2003) 513-517.

33. M. UEDA, K. G. KOSTOV, R. M. OLIVEIRA, G. S. SAVONOV, C. B MELLO, B. B. FERNANDES. IEEE Trans. Plasma Sci. 39 (10) (2011) 1998-2005. https://doi.org/10.1109/TPS.2011.2163089

34. S. MUKHERJEE, P. M. RAOLE, A. KUMAR, I. CHATTORAJ, K. R. M. RAO, I. Manna, Surf. Coat. Technol. 186 (2004) 282-286. 